\title{
Francis Adams and Songs of the Army of the Night: Negotiating Difference, Maintaining Commitment
}

\author{
MEG TASKER
}

So ONGS of the Army of the Night (1888) is a Classic of Radical socialist verse in both England and Australia. ${ }^{1}$ The author, Francis William Lauderdale Adams (1862-93), an English writer who lived in Australia for only six years but was counted by Australian nationalist critics as an Australian in spirit, demonstrates in his political verse an ability to negotiate multiple writing positions and voices in order to reach widely different readerships in both the colonies and the motherland.

This essay examines the way in which, after establishing a broad literary and journalistic reputation in both England and Australia, Adams adopted a split writing position in Songs of the Army of the Night. Comprising mostly ballads in the style of Chartist protest poetry, the Songs are intertextually determined; to some extent they have a generic life of their own. Yet in adopting the form of popular verse, using vernacular forms and diction, Adams nonetheless constructs a persona that is consistent with much of his more "literary" writing. Songs of the Army of the Night does more than demonstrate conflict in Adams' work between the claims of "art" and "life," between his upper middle-class cultural affiliations and working-class political sympathies. Despite this element of conflict, the configuration of speaking positions is not dialectic, but dialogic in the Bakhtinian sense. ${ }^{2}$ That is, the voices or speaking positions in the poetry do not work through opposition to achieve synthesis or progress, or to generate a new set of dialectical terms; rather, they co-exist in a synchronous multiplicity that allows the "implied poet" of the whole volume to be constructed as both a member of the oppressed masses and a middle-class sympathizer.

Only twenty-two when he arrived from England, Adams set out to make his mark as a fiction writer and essayist, analyzing and commenting on Australian literature and culture. Soon discovering that he could not 
live by "literary" writing alone (that is, in books and monthly or quarterly journals), he started to contribute short stories and poems to the main newspapers in Melbourne, Sydney, and Brisbane. These pieces were usually set in Australia, and generally had strong social and political themes. Adams gradually left the more conservative newspapers (or they left him) to concentrate on publishing his short stories, poems, and signed articles in the radical press. He continued to be employed in mainstream journalism, however, writing editorial leaders and book reviews for the Brisbane Courier. Although these were unsigned, and are now hard to identify as his, they earned him some distinction as a journalist. He became one of the leading political commentators in Brisbane and Toowoomba during the 1888 General Elections, and was chagrined that his colleagues at the Courier praised his leader-writing in hyperbolic terms while failing to appreciate his more artistic productions in the form of lyric and dramatic poetry, which were mostly written before he had left England. ${ }^{3}$

He wrote in a range of genres, producing at a rapid rate between 1882 and 1893 three volumes of poetry, ${ }^{4}$ six novels, ${ }^{5}$ a collection of short stories (Australian Life), a play, two collections of essays (Australian Essays, Essays in Modernity) and two books of social and political analysis (The Australians, The New Egypt). He wrote as an Anglo-Parisian "Child of the Age," in his experimental novel of that name; as a follower of Matthew Arnold in his early poetry and essays; as a "modified Arnoldian" social commentator and literary critic in his essays on Australia, and as an opinionated critic of British foreign policy in The Australians and The New Egypt. There are common themes through all his work, such as social justice, but a multiplicity of genres, voices, and implied readers. Across this diverse output, Adams addressed his work to cultural elites and scarcely literate working people, Australian nationalists, and British imperialists, men and women, artists and politicians, the mass audiences of journalism and the literary coteries who read experimental poetry.

Songs of the Army of the Night is possibly Francis Adams' best known book, and was one of the few that he still cared about when he died in 1893 at the age of thirty. It won him a hero's pedestal and occasionally a martyr's halo in the gallery of socialist poets and visionaries in England as well as Australia. Young Australian writer and woman of letters Nettie Palmer wrote in the 1940s, "Take Salt's Poems [sic] of Freedom and you will find there a few of Adams' verses splashed in burning scarlet across the dull red of the remainder." Another socialist of an earlier generation, Mary Gilmore, wrote in 1953:

No one today knows the way Francis Adams swept the feeling, young and just-awaking minds of Australia when he wrote. I wd. say that 
ninety percent of the revolutionary verse \& feeling (social \&, from it, otherwise) sprang from Adams. ${ }^{\text {? }}$

Henry Salt, English radical, friend of G. B. Shaw and Edward Carpenter, was as enthusiastic about the book as were Palmer and Gilmore. Salt not only included four of the Songs in his collection Songs of Freedom (1895), but also edited and promoted a new edition of Songs of the Army of the Night in England in 1894. According to Salt,

in their strange mixture of sweetness and bitterness, they [the Songs] are very typical of Francis Adams himself: he was at one moment, and in one aspect, the most simple and lovable of beings; at another, the most aggressively critical and fastidious. ${ }^{8}$

This dichotomy parallels, but is not congruous with, the tension between educated middle-class and oppressed working-class values in both the book and the career of its author. The expressions of passion and vigor which attracted many readers to the poems are crucial to the poet's establishment of an authentic speaking position, but Adams was as fastidious in his critique of capitalism as he was in The Australians about the philistinism of Melbourne's statuary in the 1880s. While Salt's comments have biographical interest, they do not address the problem of political commitment at the heart of Songs, a problem which prompts the poet simultaneously to examine and defend his credentials as a working-class apologist and revolutionary.

Songs of the Army of the Night offers insight into a common dilemma of the late-nineteenth-century intellectual radical, a dilemma that is manifested and to some extent addressed through the use of multiple voices to address audiences from the working/unemployed and the middle classes (in both England and Australia). In the poem "In the Camp," for instance, the poem positions the reader explicitly as "you," someone who enters the union camp, asks questions, and is answered. The poetic speaking position is one of mediation, of being familiar to the questioner and the questioned, but not apparently directly involved in the activities of the labor camp:

This is a leader's tent. 'Who gathers here?'

Enter and see and listen. On the ground

men sit or stand, enter or disappear, dark faces and deep voices all around.

One answers you. 'You ask who gathers here?

Companions! Generals we have none, nor chief,

What need is there? The plan is all so clear- 
the future's hope, the present's grim relief!

'Food for us all, and clothes, and roofs, come first.

The means to gain them? This, our leaguered band!

The hatred of the robber rich accursed

keeps foes together, makes fools understand.

'Beyond the present's faith, the future's hope

points to the dawning hour when all shall be

but one. The man condemned shall fit the rope around the hangman's neck, and both be free!

'The sun then rises on a happier land where Wealth and Labour sound but as one word.

We drill, we train, we arm our leaguered band.

What is there more to tell you have not heard?'

This is a leader's tent. They gather here, resolute, stern, menacing. On the ground they sit or stand, enter or disappear, dark faces and deep voices all around.

The quiet menace of dark figures and deep voices is an enigmatic introduction to the Songs of the Army of the Night, just as the voice of the text is enigmatically poised between the reader and the band of revolutionaries.

In his earlier poetry, learning from Browning as well as Arnold (to name only the chief English influences), Adams habitually adopted fictional voices for both narrative and lyric poems. In Henry and Other Tales (1884) and the collected Poetical Works (1887), individual speakers are relatively easy to identify as they are named at the head of sections: "Edward," "Alan," "Annie," "Frank," and so on. Within each section, the reader is directed by these headings to interpret the poems as fictionalized utterances, even when they are not obviously linked by plot or theme. End-notes to Poetical Works also direct readers to several of Adams' novels in which the same characters appear.

In Songs of the Army of the Night, however, the identity of the speaking voice is not so clearly signalled. Henry Salt some years later described Adams as having had a specific voice in mind for these poems:

Of the Songs of the Army of the Night, he said that they were intended to do what had never before been done-to express what might be the feelings of a member of the working classes as he found out the hollowness, to him, of our culture and learning. (p. 84)

Salt's reference to "our culture and learning" is telling, and it includes Francis 
Adams as a member of the more educated and refined classes. If the speaker of the Songs is fictionalized, positioned as "a member of the working classes," Salt is able to distance the "pitiless invective" of many of the poems from the poet himself, a key point both for Salt and for more hostile critics.

Salt's attempt to establish such a distance in this way is problematic for several reasons, not least because of the variety of voices and speaking positions used throughout the book. I would argue that the point Salt makes does not so much set the poet aside from the text in the ironic mode we find in, say, Browning's dramatic monologues, as add to the range of voices and discourses in the poems. Some poems are, as Salt suggests, presented as the utterances of a working-class man or woman, while others represent the point of view of a detached or sympathetic onlooker-but all these voices are necessarily within the range of the poet. More interestingly, perhaps, both positions seem also to be within the range of the "implied" poet, the poet as constructed within the text. The effect of the changes in speaking position is not to create one of those troubled midVictorian dialogues of the mind with itself that we find in the work of Clough, Arnold, and Tennyson, but to open up a range of reading positions across boundaries of social and cultural difference. The troubled dialogue, insofar as there is one, is externalized as class struggle, while the text seeks to establish a valid position for the middle-class socialist sympathizer within the political and ethical values of working-class revolt.

Most reviewers and readers seem to have been happy to give Songs of the Army of the Night the kind of author-based coherence that is associated with a Romantic poetics of the "sincere" poet, or that is constructed by a biographical literary criticism, but it is not necessary to do this in order to analyze the issues faced by the implied poet and his Preface to the volume. This implied poet has much in common with the Francis Adams who wrote so much other literary and journalistic work, but he also has a specific and unique role as the author of Songs, and he is the product not only of the text itself, but of the literary and political traditions within which this book of protest poems has been read. When I refer to Adams as the poet, it is with these qualifying comments in mind.

Adams' often declared commitment to high art, culture, and the refinements of civilized life, were clearly at odds with the democratic ideals that informed his radical zeal for social reform..$^{9}$ In the preface to the Songs, Adams expresses just such frustration, while also "owning" the ferocity that Salt explained as a fictional projection:

I make no apology for several poems in the First Part which are fierce, which are even blood-thirsty. As I felt I wrote, and I will not lessen the truth of what inspired those feelings by eliminating or 
suppressing the record of them. Rather, let me ask you, whoever you be, to imagine what the cause was, from the effect in one who was born and bred a member of the dominant class and whose chief care and joy in life was in the pursuit of a culture which draws back instinctively from the violent and terrible. I will go further. I will arraign my country and my day, because their iniquity would not let me follow out the laws of my nature, which were for luminosity and quiet, for the wide and genial view, but made me 'take arms against a sea of troubles' hoping only too often 'by opposing to end them.'

This is the stance most commonly found in Francis Adams' social criticism, although in the books and articles about Australia written after his return to England in 1890 it is tempered and often couched obliquely in diplomatic arguments aimed at a more conservative middle-class audiencethat audience which was so repelled by the ferocity of some of the Songs.

But not all of the Songs of the Army of the Night preach bloody revolution. Part II ("Australia") balances Part I ("England"), by setting hope of victory or redemption against despairing hatred, while Part III ("Here and There") uses poems from a journey in Asia to establish a broader base of indignation and hatred for the injustices and greed of the "foul sea-harlot" of British imperialism; it is not only the plight of the poor in England, and the dangers of similar class oppression occurring in Australia, but the politics of Empire that inspire the radical revolt of the Songs of the Army of the Night. These politics include a hope for a renewal of the British race and culture through its colonies, complicating the consciousness in many poems of the exploitation and "greed" of British (and other) Empire builders.

While Songs of the Army of the Night is presented by Adams' Preface as an expression of deeply felt rage by a tormented class rebel, and by his posthumous editor as the representation of a semi-fictional point of view, closer examination reveals shifts in voice and perspective that support both readings. Many poems are indeed written from the point of view of an angry proletarian, but others come from a position of middle-class support for the workers. The opening stanzas of "To an Unionist," for instance, seem to be pleading the case of the poet himself, a radical from a higher social sphere addressing those for whom he writes:

'If you only knew

how gladly I've given it

all these years-

the light of mine eyes,

the heat of my lips, 
mine agonies, my yearning tears, my blood that drips, my brain that sears: If you only knew how gladly I've given it all these yearsmy hopes and my youth, my manhood, my Art, my passion, my truth, my mind and my heart:

'O my brother, you would not say, What have you to do with me? you would not, would not turn away doubtingly and bitterly.'

In this poem Adams finds a way to make explicit an issue that, if it were unable to be expressed, might have been more debilitating. That is, the problem of the educated socialist caught between classes or social/cultural spheres who is, consequently, unable to be wholly at ease in either. The aspect of that dilemma articulated here is the problem of being taken seriously and trusted by workers in the labor movement.

Francis Adams was actively involved between 1883 and 1890 in both British and Australian labor organization and politics. His own political aspirations, Salt suggests, were cut off by the worsening of his tuberculosis, and he returned to England in 1890 with a promise to keep promoting the causes of Australian nationalism and protection. ${ }^{10}$ He was scornful of those such as Shelley whose support for political causes went, he thought, little further than sympathy in verse, or Swinburne, whose Songs before Sunrise failed to impress him:

Mr Swinburne's democracy has not the genuine ring. . . . It is one thing to sing of Socialism, the Socialism of the Italian Unionists, of the French Anti-Imperialists, of the Russian Nihilists: these are for the most part men and women of education, or, in the usual terms, gentlemen and ladies; and the enthusiastic lady or gentleman poet can enter into their point of view; but it is quite another thing to sing of the peasants and mechanics, labourers and trades-unionists, whose aims, whether for ultimate good or evil, are not in the least grasped and understood. ${ }^{11}$

Invoking this class difference, but also employing a gender demarcation to 
establish the poet's position as being one of solidarity with the workers, the poem "A Visitor In the Camp: To Mary Robinson" dramatizes the impatience of those in the union camp who see a well-meaning lady visitor as a useless intruder:

"What, are you lost, my pretty little lady?

This is not place for such sweet things as you.

Our bodies, rank with sweat, will make you sicken, and, you'll observe, our lives are rank lives too."

"Oh no, I am not lost! Oh no, I've come here, (and I have brought my lute, see, in my hand), to see you, and to sing of all you suffer to the great world, and make it understand!

"Well, say! If one of those who'd robbed you thousands, dropped you a sixpence in the gutter where you lay and rotted, would you call her angel, for all her charming smile and dainty air?"

"Oh no, I come not thus! Oh no, I've come here with heart indignant, pity like a flame, to try and help you!" - Pretty little lady, it will be best you go back whence you came.

"'Enthusiasms' we have such little time for! In our rude camp we drill the whole day long.

When we return from out the serried battle, come, and we'll listen to your pretty song!"

In Songs (and elsewhere) Francis Adams expressed respect for the women of the revolution-not only the well-born Russian anarchist Sophia Perovskaia, but ordinary shop-girls and working women involved in the new labor organizations. The immediate target in this poem is his friend, Mary Robinson (later Mary Darmesteter), whose New Arcadia was dedicated to the Cause of Labour; he describes it in a footnote to his poem as "a dilletante little book," urging her to write "poetry complete, genuine, everlasting" by sticking to more personal themes and giving up the "sympathetic rigmaroles" of social criticism. Referring also to Elizabeth Barrett Browning's "The Cry of the Children," the poet criticizes what he constructs as a middle-class dilettantism of the drawing room in order to consolidate his own position of more informed and fully engaged solidarity on the side of labor. Through a sleight of gender, in which such middle-class dilettantism is feminized, the speaker of "In the Camp" is aligned with the 
"real" soldiers of the army of the night. Women are not essentially incapable of revolt or of political commitment, as we find in other poems such as "To the Girls of the Union." The nexus of class and gender is crucial to his strategy here, with class as a critical factor, and military language and practice as markers of both masculinity and political engagement.

The militant language of revolt that Adams uses in Songs of the Army of the Night (such as the continual injunction to "Drill! Drill! Drill!") owes a good deal to the military milieu in which he spent at least some of his childhood (the pomp, glitter, and stirring sounds of the parade grounds of Malta, Ireland, Canada, and England, where his father was posted as army surgeon). In the context of Songs it serves as a guarantee of the speaker's sincerity and commitment, distancing him not only from well-meaning dilettantes of either gender, but also from the suspect role of effete poet or ineffectual angel. And yet it is important to note that the speaker of Songs of the Army of the Night is constructed as a poet. The poem "Art" explores the problem for the artist of balancing the creative urge against his fear that art itself is the product of an elitist social structure:

Yes, let Art go, if it must be that with it men must starve if Music, Painting, Poetry spring from the wasted hearth.

Pluck out the flower, however fair, whose beauty cannot bloom,

(however sweet it be, or rare) save from a noisome tomb.

These social manners, charm and ease, are hideous to [he] who knows the degradation, the disease from which their beauty flows.

So, Poet, must thy singing be:

O Painter, so thy scene;

Musician, so thy melody, while misery is queen.

Nay, brothers, sing us battle-songs with clear and ringing ryme; nay, show the world its hateful wrongs and bring the better time! ("Art," Songs, p. 25)

The problem is resolved by the dedication of poetry to protest, or to be more precise, to the writing of "battle-songs," a revolutionary touch which 
reminds us that throughout this volume of verse Adams overstepped the limits of what a fashionable socialist was supposed to support. Oscar Wilde's statement in an interview that "we are all of us more or less Socialists nowa-days ... I think I am rather more than a Socialist. I am something of an Anarchist, I believe, but, of course, the dynamite policy is very absurd indeed" is precisely the sort of attitude that Adams regarded as a dilettante pose, unlikely to effect any real social change. ${ }^{12}$

The poem "Anarchism" makes it clear that the poet of Songs does not merely sympathize with the plight of the poor, but wishes to bring about change through writing poems of protest. When he hears "the huskhearted gentleman / and the mud-hearted bourgeois" talking about liberty, order, and law,

$$
\begin{aligned}
& \text { a sombre hateful desire } \\
& \text { burns up slow in my breast } \\
& \text { to wreck the great guilty temple, } \\
& \text { and give us rest! }
\end{aligned}
$$

Such urging of the destruction of capitalist society, which could come from any of the main speaking positions identified in the poems, made it difficult for the Songs to find acceptance among proponents of bourgeois socialism such as the Fabians, whose program for reform focused on education and gradual social improvement through extension of the franchise. Adams' strong political stance inevitably polarized readers, and made his poetry difficult to sell on the general market. As the Bookman reviewer said some years later, Songs of the Army of the Night won in both Australia and England "a band of enthusiasts pro and con, but left the general public utterly cold." 13

Songs of the Army of the Night was quickly identified as a book particularly aimed at a working-class and/or socialist audience, and assessed accordingly, but the position of the author was by no means as clear as the politics of the poetry. Adams was known to some readers in both Australia and England as the author of a strange but bold piece of experimental fiction, and of lyric or narrative poetry with strong literary allusions and aspirations, all clearly the products of an educated middle-class writer. Uncertainty as to how much a particular reviewer did or did not know about Francis Adams makes it hard to interpret some reviews, but it was clear that Songs of the Army of the Night could not be judged on literary merit without some attention being paid to its politics. Nonetheless, some reviewers were less than explicit about their grounds for dissatisfaction.

The book was warmly welcomed by English radicals such as Salt, Edward Carpenter, W. M. Rossetti, and the editor of the Manchester Clarion, Robert Blatchford. Early in 1892, Carpenter sent Blatchford a copy of 
Songs of the Army of the Night to read while he was suffering from influenza; while Blatchford did not approve of the author's apparent advocacy of violence and bloodshed, he did pronounce the collection "the best democratic songs I have seen."14 Francis Adams revised the Songs for the first English publication in 1890 and another edition in 1892, and again (late in 1892) for what was to be a posthumous edition in 1894. From correspondence and the evidence of the various editions, it seems that he did not wish to soften its message, although he was prepared to do whatever was necessary to make the book acceptable to an English readership. In the English editions, the following note was inserted after the title page to explain some of the "toning down":

Note.-A few lines that were in the Australian Edition have been withdrawn in this. It is not that the Author cancels them, but that he recognizes the difference of freedom of speech in a caste and cant-ruled country like England and in a country like Australia, which is comparatively free from either cant or caste.

Adams wrote of the reception of his book in England:

At first I was a little astonished to find that the chief store of the wholesale bitterness and virulence poured on to me, for having written the 'Songs of the Army of the Night,' came from the Liberal, not the Tory, press. A gentle reproach for a really quite unjustifiable personal attack produced the reasons, with a thorough-going frankness. 'Look here, you advocate VIOLENCE, and we can't have it.' I asked: 'Where do I advocate violence?' 'It doesn't matter where; it's in the whole tone of your book.' How admirably journalistic to attack me fiercely on every other possible issue! ${ }^{15}$

Australian press reviews when the book appeared early in 1888 also avoided confronting its extreme militancy. Having been accused of "filth" in his Poetical Works by one Brisbane reviewer, Adams was now accused of not sedition or anarchy but ignorance. Rather than attacking Adams for his political views, the more conservative reviewers in both countries focused instead on the poor grammar and poetic technique of the poems, refusing to see that these were part of the book's aim to create an authentically revolutionary proletariat voice in verse. Comments in the conservative press ranged from the bland description of the Songs as "a small volume of poems that do no credit to Mr. Adams as a citizen," 16 to the Brisbane Courier reviewer's attack on his grammar, spelling, punctuation, and slovenly rhymes, all adding up to a lack of proper respect for "the established rules of his art." The values of "high art" are held up as an ideal 
against which such a raw, passionate collection of direct, confronting verse must fail.

Fred Broomfield's sympathetic review in the Sydney Bulletin took a less conservative, and less evasive, line. He attributes the roughness of technique to the demands of realism (a controversial issue of the day, which he had also discussed in reviewing Adams' "shilling dreadful," Madeline Brown's Murderer). ${ }^{17}$ In lurid tones, Broomfield defends realism, at the same time as he asserts the scholarship and artistic talent of the poet. According to Broomfield, Adams paradoxically demonstrates his literary mastery by deliberately flouting the decorous conventions of classical literature:

It is in the first part that we hear the trumpet-blast of the social message. Here the verses throb with a realistic agony, a lyric Zolaism, that chains the eyes to the page with a virile fascination. It is so simple, too- the coarse, strong meat of the poetry of first principles. The lines are hot and fervid; the poet's pulses keep time with the great heart of human woe. This is socialism in verse, anarchism in the guise of a Grecian statue. 'Outside London' breathes thick and heavy with the vapours of gutterdom. It is despair, hunger, prophecy, hate, revenge. Francis Adams, a ripe and true scholar, in this shows his devotion to truth and to art. The traditions of classicism are in this volume thrown to the winds. The poet's muse is a glorified street trull, a Cassandra of the slums, a draggle-tailed Maenad from Whitechapel, and her voice is thick and frenzied with shouting at the barricades. ${ }^{18}$

The poem Broomfield refers to here, "Outside London," is a "Proem" to the volume. Its middle stanza provides a sample of the kind of writing that made William Michael Rossetti, a government employee, feel unable to edit a posthumous edition, ${ }^{19}$ much as he admired and respected the book and its author:

The stricken men, the mad brute-beasts are keeping

no more their places in the ditches or holes,

but rise and join us, and the women, weeping

beside the roadways, rise like demon-souls.

Fill up the ranks! What shimmers there so bright?

The bayonets of the Army of the Night!

The conjunction of realism, socialism, and modernity in Adams' work is insisted on by Broomfield, who makes a virtue of the poetic crudity deplored by the majority of reviewers, particularly those who mistook the voice of 
the speakers in Songs for the voice of an uneducated Francis Adams. While Broomfield's may have been "the sole real criticism" Adams expected the Songs to receive, it was hardly impartial. Broomfield himself had overseen the publication of the book by the Federal Steam Printing and Binding Works in Sydney, while Adams, nursing his ravaged throat and lungs, convalesced in Queensland. ${ }^{20}$ Fred Broomfield was an ally, and wholeheartedly enthusiastic about Adams' work. William Lane, another close colleague of Adams, was more ambivalent. Lane was a journalist, newspaper proprietor, single-tax enthusiast, and radical Utopian socialist who would later found the optimistic New Australia commune in Paraguay. $\mathrm{He}$ and Adams differed on many points and enjoyed heated arguments about the means of bringing about a new social order. Lane's Brisbane journal, the Boomerang, gave its qualified approval to the Songs of the Army of the Night, under the sardonic heading of "Adams at it Again":

Francis W.L.'s view on things in general are certainly peculiar, but he backs them with language and brains. And since he does that we have no hesitation in recommending this little publication to anyone who has a fancy to straight hard hitting and vitriolic English. Also to those Tories who want to get a kaleidoscopic view of just what some of the other fellows think. ${ }^{21}$

Whether reviewers approved or disapproved, the conditions under which these poems were published and the political tradition within which they are so explicity located have served to focus attention on their significance as anthems of revolt, rather than as the creative work of an individual poet. While both the dramatized voices (working-class) and the less overtly fictional voice of the middle-class implied poet are "realistic," they do not sit easily with the image of Francis Adams as a fastidious, cultured child of the fin de siècle. Several poems from the Songs of the Army of the Night were published in advance in the Sydney Bulletin and the Brisbane Boomerang, and later in other radical papers such as the Brisbane Worker; a few twentieth-century anthologies, ranging from Freedom on the Wallaby (c. 1953) to, somewhat curiously, the Oxford Book of Scottish Verse (1966), included selections from the Songs. ${ }^{22}$ The curiosity of Adams' inclusion in the latter is twofold: it is one of the only occasions any of the Songs were anthologized as "poetry," rather than for their expressions of socialist thought and feeling, and it is also slightly odd that Adams, whose father's family was indeed Scottish, may never have set foot in Scotland, but nonetheless qualified for inclusion in a Scottish anthology. When Australian anthologies, such as Douglas Sladen's A Century of Australian Song (1888) and Bertram Stevens' Golden Treasury of Australian Verse (1909), included po- 
ems by Adams, they were from the more lyric and experimental Poetical Works, rather than the Songs of the Army of the Night.

As poems of protest, the Songs took on a life of their own, and Adams' cultural role is in consequence somewhat fragmented, with the socialist poetry usually being treated quite separately from most of his other work, particularly his earlier, less political, volumes of poetry. Adams was regarded by many as a bard for the cause of labor through his publication of the Songs of the Army of the Night, and because of the book's enthusiastic reception by both workers and socialist critics. Labor organizer John Phillips wrote to Victorian socialist Bernard O'Dowd in 1895:

You mention Francis Adams as the underground engineer of a great labour organization and in a similar sphere your talents must and shall be [?engaged ?employed] You are not strong enough, rough enough I mean for the hurly burly of the struggle but you can exercise in your own still silent powerful fashion an influence that the rougher type of democrat seems utterly unable to produce. Adams was no wonder and yet he seems to have done the trick-do thou likewise. ${ }^{23}$

It seems unlikely, to judge from labor history texts and public records, that Adams had any prominent role in the establishment of branches of the Australian Labour Federation, or the election campaign of the first labor candidates in Queensland in 1888, but it is clear that his radical poetry was closely tied to his work with socialist thinkers, writers, and organizers, such as William Lane and the other founders of the Australian Workers' Union (A.W.U.). When the first issue of the Brisbane Worker was published, for instance, it carried a poem specially written for the labor movement by Francis Adams, "Fling out the Flag." No doubt his personal and professional activities contributed to the enthusiastic reception of the Songs by many socialist readers, but the process has worked in both directions. In a brief eulogy published in the Communist Review, for instance, F. George reconstructed Adams as a martyr for socialism; biographically, this is an exaggerated reading of the causes of his death, but it makes perfect sense within the discourses of oppression and political hagiography.

Songs of the Army of the Night is the most uncompromising of Francis Adams' political writings. Written in the tradition of Chartist and socialist protest poetry, it was both effective and influential. Henry Lawson was working in the same radical tradition when he wrote his "The Army of the Rear" (originally entitled "Song of the Outcasts"), "Faces in the Street," and other "songs of freedom," although, unlike Mary Gilmore, he appears not to have acknowledged Adams' influence. ${ }^{24}$ But a good deal of Adams' political writing was carried on in other genres, with a more moderate tone 
and addressing a more broadly middle-class audience: novels and journalism. This need to write for multiple readerships corresponds to that other significant drive in the work of Francis Adams, and in the thinking of many a middle-class radical after him: the need to identify and develop valid roles and valid voices for social protest by those whose class and cultural affiliations would not obviously qualify them to make such protest. What is intriguing about the Songs is the way in which the poems themselves form a critique of this problem, and the way in which the classic Victorian poetic technique of using fictional speaking voices is used to forward this critique while simultaneously constructing a position of apparently unequivocal political commitment.

\section{Notes}

1 Francis Adams, Songs of the Army of the Night (Sydney, [1888]); hereafter may be referred to as Songs.

2 Mikhail Bakhtin, Problems of Dostoevsky's Poetics, ed. and trans. Caryl Emerson, introd. Wayne Booth, Theory and History of Literature, Vol. 8 (Minneapolis: Univ. of Minnesota Press, 1984). See also his The Dialogic Imagination, ed. and trans. Caryl Emerson and Michael Holquist (Texas: Texas Univ. Press, 1981).

3 FA to James Brunton Stephens, February [18 or 20], 1887, Brunton Stephens Papers, MS 3271/1, National Library of Australia (NLA). Many of the references here to manuscripts or writings about Francis Adams are quoted or discussed in more detail in Meg Tasker, Struggle and Storm: The Life and Death of Francis Adams (Melbourne: Melbourne Univ. Press, 2001).

4 Francis W. L. Adams, Henry and Other Tales (London, 1884); Poetical Works (London, 1887; Brisbane, 1887); and Songs.

5 The novels include John Webb's End (1891), Madeline Brown's Murderer (1886), The Melbournians (1892), and A Child of the Age (1894). For a complete listing of Francis Adams' work, see the Cambridge Bibliography of English Literature, Vol. 4, (1800-1900), third ed., ed. Joanne Shattock (Cambridge: Cambridge Univ. Press, 1999), col. 1448-49; Meg Tasker, Francis Adams: A Research Guide (St. Lucia: Univ. of Queensland Victorian Fiction Research Unit, 1996).

6 Nettie Palmer, typescript article on Francis Adams, Palmer Papers, NLA MS 1174/ 28.

7 W. H. Wilde and T. Inglis Moore, ed., Letters of Mary Gilmore (Carlton: Melboune Univ. Press, 1980), p. 296.

8 H. S. Salt, Seventy Years Among Savages (London: George Allen and Unwin, 1921). Salt notes: "the substance of what is here said about Francis Adams is taken from my editorial note to the revised edition of the Songs of the Army of the Night, published by Mr. A. C. Fifield, 1910."

9 Adams here differed from Henry Lawson, who was also caught between opposing cultural forces but, coming from a working-class position, had less personal investment in Culture (see Chris Lee's article in this volume). 


\section{6 / VICTORIAN POETRY}

10 Salt, p. 83. Adams had campaigned for Sir Thomas McIlwraith's "Nationalism and Protection" policies in the 1888 Queensland election, and in a letter to McIlwraith upon leaving Australia in 1890, he wrote: "In England, and in the English Press, there is a fight to be fought for your Nationalism as keen as here, and I look forward to active polemics in your behalf there before many months are over" (February 5 , 1890, Mcllwraith Papers, John Oxley Library, Queensland, OM64/19/132/2240).

11 Francis Adams, "The Poetry of Mr Swinburne," Essays in Modernity: Criticisms and Dialogue (London: John Lane, Bodley Head, 1899), p. 135.

12 Almy, "New Views of Mr O.W." in Theatre (1894): 124, cited in R. Ellmann, Oscar Wilde (London: Hamish Hamilton, 1987), p. 23n.

13 Anon., Bookman (London) 4, no 20 (May 1893): 43-44.

14 Clarion (Manchester) (February 20, 1892): 2. Transcript provided by Frank Bongiorno.

15 Francis Adams, "A Letter from England," Bulletin (July 25, 1891): 7.

16 Review, Sydney Quarterly Magazine V, no. 1 (March 1888): 96.

17 Fred Broomfield, review of Madeline Brown's Murderer, Bulletin (December 31, 1887): 9. See also Francis Adams' article on "Realism" in Centennial Magazine 1, no. 1 (August 1888): 56-60.

18 Fred Broomfield, notice of Songs of the Army of the Night included in the English editions under the heading "Australian Press Notices"-but perhaps not actually published in the Australian press.

19 W. M. Rossetti, Some Reminiscences (London: Brown, Langham \& Co., 1906), p. 505.

20 Postcard from FA to Broomfield from Toowoomba, February 2, 1888, NLA MS87/ $2 / 1$.

21 "Adams at it Again," review of Songs of the Army of the Night (while still in proof stage), Boomerang (December 10, 1887): 12.

22 Marjorie Pizer, ed., Freedom on the Wallaby: Poems of the Australian People (Sydney: Pinchgut Press, 1953); J. McQueen and T. Scott, Oxford Book of Scottish Verse (Oxford: Oxford Univ. Press, 1966).

23 J. Phillips to Bernard O'Dowd, April 10, 1895, VSL, La Trobe Library, MS 6133.

24 A Fantasy of Man: Henry Lawson Complete Works, 1901-1922, Vol 1, ed. Leonard Cronin (Sydney: Lansdowne, 1984), p. vi. 